\title{
KAJIAN KRITIS ATAS KEWENANGAN PRESIDEN UNTUK MEMBATALKAN PERATURAN DAERAH DALAM OMNIBUS LAW
}

(Critical Study of the President's Authority to Cancel The Regional Regulations in Omnibus Law)

\author{
Tohadi \\ Universitas Pamulang \\ Jalan Surya Kencana No.1 Pamulang, Tangerang Selatan \\ e-mail: mohtohadi@gmail.com
}

Naskah diterima: 17 Februari 2020; revisi: 3 April 2020; disetujui: 6 April 2020

\begin{abstract}
Abstrak
Kebijakan Presiden Jokowi mengajukan metode omnibus law melalui RUU Cipta Kerja untuk menciptakan lapangan kerja patut diapresiasi. Namun demikian, harus tetap sejalan dengan prinsip negara demokrasi konstitusional (negara hukum) yang kita sepakati. Penelitian ini membahas Putusan MK No. 137/PUU-XIII/2015 tanggal 5 April 2017 dan Putusan MK No. 56/PUU-XIV/2016 tanggal 14 Juni 2018 terkait pembatalan Perda dan pengaturan kewenangan Presiden untuk membatalkan Perda sebagaimana Pasal 166 angka 3 RUU Cipta Kerja yang mengubah ketentuan Pasal 251 UU Pemerintahan Daerah dikaitkan dengan kedua Putusan MK tersebut maupun menurut teori hukum. Penelitian ini merupakan penelitian normatif dengan menggunakan studi kepustakaan atau data sekunder. Hasil penelitian menyimpulkan kedua putusan MK dalam pertimbangan hukumnya menyatakan bahwa pembatalan Perda dalam hal ini Perda Kabupaten/Kota dan/ atau Perda Provinsi menjadi ranah kewenangan konstitusional Mahkamah Agung (MA). Pengaturan kewenangan Presiden untuk membatalkan Perda dalam RUU Cipta Kerja tidak tepat jika dianalisis dari teori hukum. Karena tidak sejalan dengan Putusan MK, ketentuan undang-undang terkait, dan kewenangan atributif yang dimiliki Mahkamah Agung (MA) sebagai lembaga yang berwenang secara konstitusional membatalkan Perda.
\end{abstract}

Kata kunci: omnibus law, omnibus bill, Peraturan Daerah

\begin{abstract}
The President Jokowi's policy proposing the omnibus law method through the Employment Creation Bill to create employment deserves to be appreciated. However, it must remain in line with the principles of the constitutional democratic state (rule of law) that we agreed upon. This research discusses about MK Decision Number 137 / PUU-XIII/2015 dated 5 April 2017 and MK Decision Number 56/PUU-XIV/2016 dated June 14, 2018 related to the cancellation of Regional Regulations (Perda), and how is the regulation of the President's authority to cancel the Perda as Article 166 number 3 of the Employment Creation Billamending the provisions of Article 251 of the Law on Regional Governments related with the two Constitutional Court Decisions as well as according to legal theory. This research is a normative research using library research or secondary data. The results conclude that the two decisions of the Constitutional Court in its legal considerations state that the cancellation of the Regional Regulation in this case a District/City and/or a Provincial Regulation becomes the domain of the Supreme Court (MA). Thus, the regulation of the President's authority to revoke the Regional Regulation in the Employment Creation Billis is incorrect if analyzed from legal theory. Because it is not in line with the Constitutional Court's Decision, the provisions of related laws, and attributive authority possessed by the Supreme Court (MA) as an institution that has the constitutional authority to cancel the Regional Regulation.

Keywords : omnibus law, omnibus bill, Local Regulation
\end{abstract}




\section{A. Pendahuluan}

Salah satu babak sejarah penting pada masa pemerintahan Presiden Joko Widodo (Jokowi) adalah diajukannya omnibus law. Presiden Jokowi menyampaikan keinginan digunakannya omnibus law pada Sidang Paripurna MPR RI dalam Rangka Pelantikan Presiden dan Wakil Presiden Periode 20192024, tanggal20 Oktober 2019. Jokowi dalam pidatonya menyampaikan yang akan dikerjakan 5 tahun kedepan, antara lain: 1). Membangun SDM yang pekerja keras, yang dinamis; 2). Pemerintah akan mengajak DPR untuk menerbitkan UU Cipta Lapangan Kerja yang menjadi omnibus law untuk merevisi puluhan UU yang menghambat penciptaan lapangan kerja dan yang menghambat pengembangan UMKM; dan 3).Investasi untuk penciptaan lapangan kerja harus diprioritaskan dan prosedur yang panjang harus dipotong. ${ }^{1}$

Sebelumnya, Menteri Agraria dan Tata Ruang/Kepala Badan Pertanahan Nasional Sofyan Djalil pernah melontarkan konsep omnibuslaw. ${ }^{2}$ Di negara yang menganut sistem common law seperti Amerika Serikat, konsep ini dikenal dengan omnibus bill, yang sering digunakan dalam membuat regulasi. Regulasi dalam konsep ini adalah membuat satu UU baru untuk mengamandemen beberapa UU sekaligus. ${ }^{3}$
Pernyataan Sofyan Djalil tersebut muncul karena tumpang tindihnya regulasi, khususnya menyoal investasi. Sofyan mencontohkan, ketika ada usulan memperbaiki regulasi di bidang kehutanan maka yang harus direvisi adalah UU No. 41 Tahun 1999 tentang Kehutanan. Namun, masih ada ganjalan dalam beleid lain, semisal UU No. 32 Tahun 2009 tentang Perlindungan dan Pengelolaan Lingkungan Hidup (PPLH) atau UU No. 5 Tahun 1960 tentang Peraturan Dasar Pokok-Pokok Agraria. ${ }^{4}$

Metode omnibus law yang dipilih Presiden Jokowi untuk melakukan perubahan sejumlah undang-undang didasarkan pada alasan adanya hyper regulasi atau obesitas regulasi. Menurut Jokowi, hingga kini ada sekitar 8.451 peraturan pusat dan 15.985 peraturan daerah. Jumlah yang dianggapnya terlalu banyak dan perlu dipangkas. ${ }^{5}$ Lebih lanjut, Jokowi mengatakan bahwa terlalu banyak dan terlalu kakunya aturan tersebut membuat Indonesia kalah dalam berkompetisi dengan negara lain. ${ }^{6}$

Pada 12 Februari 2020 Presiden Jokowi resmi mengajukan omnibus law ke Dewan Perwakilan Rakyat Republik Indonesia (DPR RI). Melalui Menteri Koordinator Bidang Ekonomi Bersama Menteri terkait lainnya, Presiden Jokowi menyerahkan Surat Presiden RI Nomor: R-06/Pres/02/2020 tanggal 7

\footnotetext{
Kementerian Koordinator Bidang Perekonomian Republik Indonesia, "Omnibus Law Cipta Lapangan Kerja", hlm. 4.

2 Lihat Hukum Online, Menimbang Konsep Omnibus Law Bila Diterapkan di Indonesia, https://www.hukumonline. com/berita/baca/lt58a6fc84b8ec3/menimbang-konsep-omnibus-law-bila-diterapkan-di-indonesia/ (diakses 11 Februari 2020).

5 Lihat Detik.com, Alasan Jokowi Kebut Omnibus Law: Kita Mengalami Obesitas Regulasi, https://finance.detik. com/berita-ekonomi-bisnis/d-4875968/alasan-jokowi-kebut-omnibus-law-kita-mengalami-obesitasregulasi(diakses pada tanggal 15 Februari 2020).
}

3 Ibid.

$4 \quad$ Ibid.

6 Ibid. 
Februari 2020 perihal Rancangan UndangUndang tentang Cipta Kerja (RUU Cipta Kerja) kepada Ketua DPR RI yang disertai dokumen (hard copy) Naskah Akademik dan RUU Cipta Kerja.

Dalam konsiderans huruf e RUU Cipta Kerja dinyatakan bahwa pembentukan Undang-Undang dengan menggunakan metode omnibus law didasarkan bahwa upaya perubahan pengaturan yang berkaitan kemudahan dan perlindungan usaha mikro, kecil, dan menengah, peningkatan ekosistem investasi, dan percepatan proyek strategis nasional, termasuk peningkatan perlindungan dan kesehatan pekerja yang dilakukan melalui perubahan Undang-Undang sektoral yang dilakukan secara parsial tidak efektif dan efisien untuk menjamin percepatan cipta kerja.

Selanjutnya Pasal 3 RUU Cipta Kerja menyatakan bahwa tujuan diselenggarakannya omnibus law in casu RUU Cipta Kerja untuk menciptakan lapangankerja yang seluasluasnya bagi rakyat Indonesia secara merata di seluruh wilayah Negara Kesatuan Republik Indonesia dalam rangka memenuhi hak atas penghidupan yang layak melalui kemudahan dan perlindungan UMK-M serta perkoperasian, peningkatan ekosistem investasi, kemudahan berusaha, peningkatan perlindungan dan kesejahteraan pekerja, investasi Pemerintah Pusat dan percepatan proyek strategis nasional.

Untuk mencapai tujuan tersebut, Pasal 4 ayat (1) dan (2) RUU Cipta Kerja mengatur mengenai kebijakan strategis Cipta Kerja yang memuat kebijakan penciptaan atau perluasan lapangan kerja melalui pengaturan yang terkait dengan: a.Peningkatan ekosistem investasi dan kegiatan berusaha; b.Peningkatan perlindungan dan kesejahteraan pekerja; c.kemudahan, pemberdayaan, dan perlindungan UMK-M serta perkoperasian; dan d. peningkatan investasi pemerintah dan percepatan proyek strategis nasional.

Dalam rangka mendukung kebijakan strategis Cipta Kerja diperlukan pengaturan mengenai pelaksanaan administrasi pemerintahan dan pengawasan, pembinaan, dan pengenaan sanksi. ${ }^{7}$ Salah satu dari pelaksanaan administrasi pemerintahan menurut RUU Cipta Kerja adalah adanya kewenangan Presiden untuk membatalkan Peraturan Daerah (Perda) baik Perda Kabupaten/Kota maupun Perda Provinsi.

Dalam Pasal 166 angka 3 RUU Cipta Kerja dinyatakan bahwa ketentuan Pasal 251 Undang-Undang Nomor 23 Tahun 2014 tentang Pemerintahan Daerah sebagaimana diubah terakhir dengan Undang-Undang Nomor 9 Tahun 2015 tentang Perubahan Kedua atas Undang-Undang Nomor 23 Tahun 2014 tentang Pemerintahan Daerah (selanjutnya disingkat UU Pemda) diubah sehingga berbunyi sebagai berikut:

Pasal 251

(1) Perda Provinsi dan peraturan gubernur dan/atau Perda Kabupaten/Kota dan peraturan bupati/walikota, yang bertentangan dengan ketentuan peraturan perundang-undangan yang lebih tinggi dan asas-asas pembentukan peraturan perundang-undangan yang baik dapat dibatalkan.

(2) Perda Provinsi dan peraturan gubernur dan/atau Perda Kabupaten/ Kota dan peraturan bupati/walikota

Lihat Pasal 5 RUU Cipta Kerja 
sebagaimana dimaksud pada ayat (1) dicabut dan dinyatakan tidak berlaku dengan Peraturan Presiden.

Pasal 166 angka 3 RUU Cipta Kerja telah mengubah ketentuan Pasal 251 UU Pemda dimana menentukan bahwa Perda Provinsi dan peraturan gubernur dan/ atau Perda Kabupaten/Kota dan Peraturan Bupati/Walikota dicabut dan dinyatakan tidak berlaku dengan Peraturan Presiden. Pengaturan ini menentukan bahwa Presiden memiliki kewenangan untuk mencabut dan menyatakan tidak berlaku (membatalkan) Perda dan Perkada.

Ketentuan a quo tidak sejalan dengan putusan Mahkamah Konstitusi (MK) yang ada, yaitu Putusan MK No. 137/PUUXIII/2015 tanggal 5 April 2017 dan Putusan MK No. 56/PUU-XIV/2016 tanggal 14 Juni 2018. Kedua Putusan MK ini pada pokoknya menyatakan dalam pertimbangan hukumnya bahwa pembatalan Perda dalam hal ini Perda Kabupaten/Kota dan/atau Perda Provinsi menjadi ranah kewenangan konstitusional Mahkamah Agung (MA).

Berdasarkan hal diatas, penulis tertarik untuk menganalisis, "Kajian Kritis Atas Kewenangan Presiden Untuk Membatalkan Perda dalam Omnibus Law". Penulis akan melihat, pertama, bagaimana Putusan MK No. 137/PUU-XIII/2015 tanggal 5 April 2017 dan Putusan MK No. 56/PUU-XIV/2016 tanggal 14 Juni 2018 terkait pembatalan Perda, dan kedua, bagaimana pengaturan kewenangan Presiden untuk membatalkan Perda dalam RUU Cipta Kerja dikaitkan dengan kedua
Putusan MK tersebut maupun menurut teori perubahan peraturan perundang-undangan dan teori kewenangan lembaga negara.

\section{B. Metode Penelitian}

Penelitian ini merupakan penelitian normatif dengan melakukan penelitian kepustakaan atau data sekunder. ${ }^{8}$ Data sekunder yang digunakan dalam penelitian ini menggunakan bahan hukum primer yang meliputi RUU tentang Cipta Kerja, UU No. 30 Tahun 2014 tentang Administrasi Pemerintahan, UU No. 23 Tahun 2014 tentang Pemerintahan Daerah sebagaimana diubah terakhir dengan UU No. 9 Tahun 2015, UU No. 12 Tahun 2011 tentang Pembentukan Peraturan Perundang-undangan sebagaimana telah diubah dengan UU No. 15 Tahun 2019, UU No. 48 Tahun 2009 tentang Kekuasaan Kehakiman, UU No. 14 Tahun 1985 tentang Mahkamah Agung sebagaimana diubah terakhir dengan UU No. 3 Tahun 2009, Putusan MK No. 137/PUU-XIII/2015 tanggal 5 April 2017, dan Putusan MK No. 56/PUUXIV/2016 tanggal 14 Juni 2018. Bahan hukum sekunder mengacu pada buku-buku atau literatur hukum. Sedangkan bahan tersier dipergunakan kamus hukum dan ensiklopedia hukum.

Sifat penelitian ini merupakan penelitian deskriptif, dimaksudkan untuk mengumpulkan informasi mengenai status suatu variabel atau tema, gejala atau keadaan yang ada, yaitu keadaan gejala menurut apa adanya pada saat penelitian dilakukan. ${ }^{9}$ Penelitian 
deskriptif bertujuan menggambarkan secara lengkap ciri-ciri dari suatu keadaan, perilaku pribadi dan perilaku kelompok, serta untuk menentukan frekuensi suatu gejala. ${ }^{10}$

Penelitian penulis akan menggambarkan bagaimana kewenangan Presiden untuk membatalkanPerda dalam omnibus law dikaitkan dengan Putusan MK No. 137/PUUXIII/2015 tanggal 5 April 2017 dan Putusan MK No. 56/PUU-XIV/2016 tanggal 14 Juni 2018 maupun menurut teori hukum.

Penelitian ini menggunakan analisis data secara kualitatif. Data-data yang terkumpul ditafsirkan untuk menjawab permasalahan yang ada dalam penelitian. ${ }^{11}$

Dalam menganalisis mengenai kewenangan Presiden untuk membatalkan Perda dalam omnibus law di atas, penulis menggunakan teori putusan khususnya mengenai pertimbangan hakim, teori perubahan undang-undang, dan teori kewenangan khususnya kewenangan atributif yang dimiliki oleh MK dan MA.

Dengan teori putusan utamanya mengenai pertimbangan hakim akan melihat bagaimana arah dan maksud sebenarnya (original intent) dari Mahkamah sebagaimana dalam kedua Putusan MK di atas mengenai pembatalan Perda, baik Perda Provinsi maupun Perda Kabupaten/Kota. Teori perubahan undangundang digunakan untuk melihat apakah metode omnibus law terkait pembatalan Perda tersebut mampu menjawab persoalan inkonsistensi undang-undang. Adapun teori kewenangan khususnyakewenangan atributif digunakan untuk menganalisis siapa yang memiliki kewenangan terkait pembatalan
PerdaProvinsi dan/atau Perda Kabupaten/ Kota sesuai peraturan perundang-undangan.

\section{Pembahasan}

1. Pembatalan Perda Menurut Putusan MK No. 137/PUU-XIII/2015 tanggal 5 April 2017 dan Putusan MK No. 56/ PUU-XIV/2016 tanggal 14 Juni 2018

a. Pembatalan Perda Kabupaten/Kota Menurut Putusan MK No. 137/PUUXIII/2015 tanggal 5 April 2017

Putusan MK No. 137/PUU-XIII/2015 tanggal 5 April 2017 merupakan putusan atas permohonan uji materiil (judicial review) atas berlakunya Pasal 9; Pasal 11; Pasal 12; Pasal 13; Pasal 14 ayat (1), ayat (2), ayat (3), dan ayat (4); Pasal 15; Pasal 16 ayat (1) dan ayat (2); Pasal 17 ayat (1), ayat (2), dan ayat (3); Pasal 21; Pasal 27 ayat (1) dan ayat (2); Pasal 28 ayat (1) dan ayat (2); Pasal 251 ayat (2), ayat (3), dan ayat (8) serta ayat (4) UU Pemda sepanjang frasa "...pembatalan Perda Kabupaten/Kota dan peraturan bupati/ wali kota sebagaimana dimaksud pada ayat (2) ditetapkan dengan keputusan gubernur sebagai wakil Pemerintah Pusat".

Adapun yang terkait dengan pembatalan Perda Kabupaten/Kota serta mekanisme keberatan pembatalannya adalah mengenai pengujian konstitusionalitas Pasal 251 ayat (2), ayat (3), ayat (4), dan ayat (8) UU Pemda.

Pasal 251 ayat (2), ayat (3), ayat (8), dan ayat (4) UU Pemda sepanjang frasa "pembatalan perda Kabupaten/Kota dan peraturan Bupati/Walikota sebagaimana dimaksud pada ayat (2) ditetapkan dengan keputusan

10 SoerjonoSoekanto, Op. Cit., hlm. 49, 53, dan 96.

11 Maria S.W. dan Sumardjono, Pedoman Pembuatan Usulan Penelitian(Yogyakarta: t.p, 1989 hlm. 24). 
Gubernur sebagai wakil Pemerintah Pusat" selengkapnya berbunyi:

(2) Perda Kabupaten/Kota dan peraturan Bupati/Walikota yang bertentangan dengan ketentuan peraturan perundang-undangan yang lebih tinggi, kepentingan umum dan/atau kesusilaan dibatalkan oleh Gubernur sebagai wakil Pemerintah Pusat;

(3) Dalam hal gubernur sebagai wakil Pemerintah Pusat tidak membatalkan Perda Kabupaten/Kota dan/atau peraturan bupati/wali kota yang bertentangan dengan ketentuan peraturan perundang- undangan yang lebih tinggi, kepentingan umum, dan/ atau kesusilaan sebagaimana dimaksud pada ayat (2), Menteri membatalkan Perda Kabupaten/Kota dan/atau peraturan bupati/wali kota;

(4) Pembatalan perda Kabupaten/ Kota dan peraturan Bupati/ Walikotasebagaimana dimaksud pada ayat (2) ditetapkan dengan keputusan Gubernur sebagai wakil Pemerintah Pusat.

(8) Dalam halpenyelenggaraPemerintahan Daerah Kabupaten/Kota tidak dapat menerima keputusan pembatalan perda kabupaten/kota dan bupati/walikota tidak dapat menerima keputusan pembatalan peraturan bupati/walikota sebagaimana dimaksud pada ayat (4) dengan alasan yang dapat dibenarkan oleh ketentuan peraturan perundangundangan, Bupati/walikota dapat mengajukan keberatan kepada Menteri paling lambat 14 hari (empat belas) hari sejak keputusan pembatalan Perda Kabupaten/Kota atau Peraturan Bupati/Walikota diterima.

Mahkamah Konstitusi dalam salah satu amar Putusan MK No. 137/PUU-XIII/2015 tanggal 5 April 2017:

"Menyatakan frasa "Perda Kabupaten/ Kota dan" dalam Pasal 251 ayat (2) dan ayat (4), frasa "Perda Kabupaten/Kota dan/atau" dalam Pasal 251 ayat (3), dan frasa "penyelenggara Pemerintah Daerah kabupaten/kota tidak dapat menerima keputusan pembatalan Perda Kabupaten/ Kota dan" dan frasa" Perda Kabupaten/Kota atau" dalam Pasal 251 ayat (8) UndangUndang Nomor 23 Tahun 2014 tentang Pemerintahan Daerah bertentangan dengan Undang-Undang Dasar Negara Republik Indonesia Tahun 1945 dan tidak mempunyai kekuatan hukum mengikat".

Menurut Majelis Mahkamah Konstitusi (Mahkamah) dalam pertimbangan hukum Putusan MK No. 137/PUU-XIII/2015 tanggal 5 April 2017 a quo, bahwa Perda oleh karena sebagai produk para wakil rakyat bersama dengan pemerintah daerah, maka dapat disebut sebagai produk legislatif, sama seperti halnya undang-undang. Perbedaan antara keduanya, Perda dengan UndangUndang, menurut Mahkamah hanya dari segi lingkup teritorial atau wilayah berlakunya, yakni bersifat nasional atau lokal. UndangUndang berlaku secara nasional, sedangkan Perda hanya berlaku di dalam wilayah pemerintahan daerah yang bersangkutan, yaitu dalam wilayah daerah provinsi, wilayah daerah kabupaten, atau wilayah daerah kota yang bersangkutan. Karena itu, peraturan daerah itu tidak ubahnya adalah "local law" atau "locale wet", yaitu undang-undang yang bersifat lokal (local legislation). ${ }^{12}$

Namun demikian, menurut Mahkamah, dari segi isinya sudah seharusnya kedudukan peraturan yang mengatur materi dalam ruang lingkup daerah berlaku yang lebih sempit dianggap mempunyai kedudukan lebih rendah dibandingkan peraturan dengan 
ruang lingkup wilayah berlaku yang lebih luas. Dengan demikian, Undang-Undang lebih tinggi kedudukannya daripada Perda Provinsi dan Perda Kabupaten/Kota. ${ }^{13}$

Perda dibentuk berdasarkan asas kedaulatan rakyat, karena dibentuk oleh lembaga eksekutif dan legislatif. Secara formil, menurut Mahkamah, pembentukan Perda sebagai hasil manifestasi kedaulatan rakyat yang dilakukan melalui Kepala Daerah dan DPRD setempat. Kedaulatan rakyat sebagaimana diketahui, merupakan amanah Pasal 1 ayat (2) UUD 1945. ${ }^{14}$

Meskipun dalam perspektif negara kesatuan (unitary state, eenheidsstaat) seperti halnya NKRI berdasarkan UUD 1945 menyatakan bahwa pemerintah pusat berwenang melakukan kontrol terhadap pemerintah daerah. Namun demikian, yang dikendalikan atau dikontrol oleh pemerintah pusat itu antara lain misalnya melalui kewenangan untuk melakukan "executive abstract preview", bukan mekanisme "review" atas peraturan daerah yang sudah berlaku mengikat untuk umum. ${ }^{15}$

Oleh karena itu menurut Mahkamah terhadap peraturan daerah sebagai produk legislatif di daerah, sebaiknya hanya di "preview" oleh pemerintahan atasan apabila statusnya masih sebagai rancangan peraturan daerah yang belum mengikat untuk umum. Jika peraturan daerah itu sudah mengikat umum, maka sebaiknya yang mengujinya adalah lembaga peradilan sebagai pihak ketiga yang sama sekali tidak terlibat dalam proses pembentukan peraturan daerah yang bersangkutan sesuai dengan sistem yang dianut dan dikembangkan menurut UUD 1945 yakni "centralized model of judicial review", bukan "decentralized model", seperti ditentukan dalam Pasal 24A ayat (1) dan Pasal 24C ayat (1) UUD 1945. ${ }^{16}$

Pasal 245 UU Pemda memberikan kewenangan pengawasan preventif kepada Gubernur sebagai wakil Pemerintah Pusat untuk mengevaluasi rancangan peraturan daerahkabupaten/kotayang mengaturtentang Rencana Pembangunan Jangka Panjang Daerah (RPJPD), Rencana Pembangunan Jangka Menengah Daerah (RPJMD), Anggaran Pendapatan dan Belanja Daerah (APBD), perubahan APBD, pertanggungjawaban pelaksanaan APBD, pajak daerah, retribusi daerah, dan tata ruang daerah sebelum ditetapkan oleh bupati/walikota.

Adanya ketentuan Pasal 251 ayat (2) dan ayat (3) UU Pemda yang memberi wewenang kepada Menteri dan gubernur sebagai wakil Pemerintah Pusat untuk membatalkan Perda Kabupaten/Kota yang bertentangan dengan ketentuan peraturan perundang-undangan yang lebih tinggi, menurut Mahkamah, pertama, menyimpangi logika dan bangunan negara hukum Indonesia sebagaimana amanah Pasal 1 ayat(3) UUD 1945. Kedua, menegasikan peran dan fungsi Mahkamah Agung sebagai lembaga yang berwenang melakukan pengujian peraturan perundangundangan di bawah Undang-Undang in casu Perda Kabupaten/Kota sebagaimana

\footnotetext{
13 Putusan MK No. 137/PUU-XIII/2015 tanggal 5 April 2017 hlm. 202.

14 Putusan MK No. 137/PUU-XIII/2015 tanggal 5 April 2017 hlm. 203.

15 Putusan MK No. 137/PUU-XIII/2015 tanggal 5 April 2017 hlm. 204.

16 Putusan MK No. 137/PUU-XIII/2015 tanggal 5 April 2017 hlm. 204.
} 
ditegaskan dalam Pasal 24A ayat (1) UUD 1945. ${ }^{17}$

Adapun pembatalan Perda Kabupaten/ Kota melalui Keputusan Gubernur sebagai wakil Pemerintah Pusat sebagaimana dimaksud dalam Pasal 251 ayat (4) UU Pemda, menurut Mahkamah, pertama, tidak sesuai dengan rezim peraturan perundangundangan yang dianut Indonesia. Mahkamah merujuk Pasal 7 ayat (1) dan Pasal 8 UU $12 / 2011$ menyatakan bahwa tidak mengenal Keputusan Gubernur sebagai salah satu jenis dan hierarki peraturan perundangundangan. Dengan demikian, kedudukan Keputusan Gubernur bukanlah bagian dari rezim peraturan perundang-undangan, sehingga tidak dapat dijadikan produk hukum untuk membatalkan Perda Kabupaten/Kota. Dengan kata lain, menurut Mahkamah, terjadi kekeliruan dimana Perda Kabupaten/ Kota sebagai produk hukum yang berbentuk peraturan (regeling) dapat dibatalkan dengan keputusan gubernur sebagai produk hukum yang berbentuk keputusan (beschikking).

Kedua, ekses dari produk hukum pembatalan Perda dalam lingkup eksekutif dengan produk hukum ketetapan gubernur sebagaimana ditentukan dalam Pasal 251 ayat (4) UU Pemda berpotensi menimbulkan dualisme putusan pengadilan jika kewenangan pengujian atau pembatalan Perda terdapat pada lembaga eksekutif dan lembaga yudikatif. ${ }^{18}$ Adanya dualism putusan pengadilan seperti itu akan menimbulkan ketidakpastian hukum, padahal kepastian hukum merupakan hak setiap orang yang dijamin dan dilindungi oleh Pasal 28D ayat (1) UUD 1945. Oleh karena itu, menurut Mahkamah, demi kepastian hukum dan sesuai dengan UUD 1945 menurut Mahkamah pengujian atau pembatalan Perda menjadi ranah kewenangan konstitusional Mahkamah Agung. ${ }^{19}$

Berdasarkan uraian di atas, Pasal 251 ayat (2), ayat (3), dan ayat (4) UU Pemda sepanjang mengenai Perda Kabupaten/Kota, menurut Mahkamah, bertentangan dengan UUD 1945. ${ }^{20}$ Dengan demikian, menurut Mahkamah, Pasal 251 ayat (8) UU Pemda menjadi kehilangan relevansi, oleh karenanya Pasal 251 ayat (8) UU Pemda sepanjang mengenai Perda Kabupaten/Kota juga harus dinyatakan bertentangan dengan UUD 1945. ${ }^{21}$

\section{b. Pembatalan Perda Provinsi Menurut Putusan MK No. 56/PUU-XIV/2016 tanggal 14 Juni 2018}

Putusan MK No. 56/PUU-XIV/2016 tanggal

14 Juni 2018, dalam salah satu amarnya:

"Menyatakan frasa "Perda Provinsi dan" dalam Pasal 251 ayat (1) dan ayat (4), dan frasa "Perda Provinsi dan" dalam Pasal 251 ayat (7), serta Pasal 251 ayat (5) UndangUndang Nomor 23 Tahun 2014 tentang Pemerintahan Daerah (Lembaran Negara Republik Indonesia Tahun 2014 Nomor 244, Tambahan Lembaran Negara Republik Indonesia Nomor 5587) bertentangan dengan Undang-Undang Dasar Negara Republik Indonesia Tahun 1945 dan tidak mempunyai kekuatan hukum mengikat."

Putusan MK No. 137/PUU-XIII/2015 tanggal 5 April 2017 hlm. 205.

Putusan MK No. 137/PUU-XIII/2015 tanggal 5 April 2017 hlm. 205-206.

Putusan MK No. 137/PUU-XIII/2015 tanggal 5 April 2017 hlm. 206.

Putusan MK No. 137/PUU-XIII/2015 tanggal 5 April 2017 hlm. 206.

Putusan MK No. 137/PUU-XIII/2015 tanggal 5 April 2017 hlm. 207. 
Putusan MK a quo merupakan putusan atas permohonan uji materiil atas Pasal 251 ayat (1), ayat (2), ayat (7), dan ayat (8) UU Pemda.

Pertimbangan Mahkamah dalam Putusan MK No. 56/PUU-XIV/2016 tanggal 14 Juni 2018 ini menukil pertimbangan Mahkamah pada putusan sebelumnya, yaitu Putusan MK No. 137/PUU-XIII/2015 tanggal 5 April 2017 bahwa pembatalan Perda Kabupaten/Kota melalui mekanisme executive review adalah bertentangan dengan UUD 1945.

Dengan mengacu pada pertimbangan tersebut, selanjutnya Mahkamah dalam pertimbangan Putusan MK No. 56/PUUXIV/2016 tanggal 14 Juni 2018 menyatakan bahwa:

Oleh karena dalam Pasal 251 ayat (1) dan ayat (4) UU 23/2014 mengatur mengenai pembatalan Perda Provinsi melalui mekanisme executive review maka pertimbangan hukum dalam Putusan Nomor 137/PUU-XIII/2015, bertanggal 5 April 2017 berlaku pula untuk permohonan para Pemohon a quo. Sehingga Mahkamah berpendapat, Pasal 251 ayat (1) dan ayat (4) UU 23/2014 sepanjang mengenai frasa "Perda Provinsi dan" bertentangan dengan UUD 1945. ${ }^{22}$

Putusan MK No. 56/PUU-XIV/2016 tanggal 14 Juni 2018, dengan demikian, menegaskan bahwa pengujian atau pembatalan Perda in casu Perda Gubernur menjadi ranah kewenangan konstitusional Mahkamah Agung.

\section{Kewenangan Presiden Untuk Membatalkan Perda dalam Omnibus Law}

Omnibus law merupakan konsep yang ada dan dipraktikkan dalam negara yang menganut common law system. Konsep ini bertujuan untuk memperbaiki regulasi dinegaranya masing-masing dalam rangka meningkatkan iklim dan daya saing investasi. ${ }^{23}$

Dalam negara dengan system hokum public tersebut dikenal dengan istilah omnibus bill.

Adam M. Dodek, ilmuwan dari Fakultas Hukum Universitas Ottawa (Faculty of Law, University of Ottawa) mengatakan mengenai definisi omnibus bill, sebagaiberikut:

The House of Commons Procedure and Practice handbook states that "there is no precise definition of an omnibus bill." However, it proceeds to explain that generally, "an omnibus bill seeks to amend, repeal or enact several Acts, and is characterized by the fact that it is made up of a number of related but separate initiatives."

(Buku pegangan Prosedur dan Praktek House of Commons menyatakan bahwa "Tidak ada definisi yang tepat dari RUU omnibus." Namun, merupakan prosedur untuk menjelaskan bahwa secara umum, "RUU omnibus berupaya untuk mengubah, mencabut, atau memberlakukan beberapa undang-undang, dan dicirikan oleh fakta bahwa itu terdiri dari sejumlah inisiatif terkait tetapi terpisah)." 24

Louis Massicotte mengidentifikasi dua keuntungan berbeda dari pemerintah yang menggunakan omnibus bill. Pertama, omnibus bill menghemat waktu dan

Putusan MK No. 56/PUU-XIV/2016 tanggal 14 Juni 2018 hlm. 99.

23 Kementerian Koordinator Bidang Perekonomian Republik Indonesia, "Omnibus Law Cipta Lapangan Kerja",Op. Cit., hlm. 14.

24 Adam M. Dodek, "Omnibus Bills: Constitutional Constraints and Legislative Liberations", Ottawa Law Review, Vol. 48, No. 1, (2017): 12. Lihat juga https://papers.ssrn.com/sol3/papers.cfm?abstract_id=2889773 (diakses pada 11 Februari 2020). 
mempersingkat proses legislative dengan menghindari persiapan puluhan undangundang yang berbeda, yang masing-masing akan memerlukan debat. Kedua, mereka menimbulkan rasa malu bagi partai-partai oposisi dengan mengisolasi proposalproposal yang sangat kontroversial dalam paket legislatif yang kompleks, yang bagianbagiannya bisa sangat populer di masyarakat atau bahkan dengan partai-partai oposisi sendiri. ${ }^{25}$

Omnibus law terdiri dari kata "omnibus" dan "law". Kata omnibus berasal dari bahasa Latin dan berarti untuk semuanya. Di dalam Black Law Dictionary Ninth Edition Bryan A.Garner disebutkan omnibus: relating to or dealing with numerous object or item at once; inculding many thing or having varius purposes, yang berarti berkaitan dengan atau berurusan dengan berbagai objek atau item sekaligus; termasuk banyak hal atau memiliki berbagai tujuan. Jika dipasangkan dengan kata Law, maka dapat didefinisikan sebagai hukum untuk semua. ${ }^{26}$

Omnibus law merupakan metode yang digunakan untuk mengganti dan/atau mencabut beberapa materi hukum dalam berbagai UU. ${ }^{27}$ Omnibus law merupakan metode penyusunan peraturan atau norma hukum, yang mana dalam satu peraturan akan terdapat substansi/materi untuk menegasikan norma-norma hokum sebelumnya yang tersebar dalam beberapa produk regulasi, dan ketika peraturan baru ini diundangkan maka akanmencabut materi-materi dalam peraturan sebelumnya. ${ }^{28}$

Omnibus law sejatinya adalah teknik dalam penyusunan UU yang bertujuan untuk mewujudkan efisiensi dan efektivitas. Materi muatannya adalah ketentuan-ketentuan dasar yang menjadi acuan bagi kementerian atau lembaga lain. ${ }^{29}$ Omnibus law dalam bentuk UU bukan UU Pokok, tetapi UU yang setara dengan UU lain yang seluruh atau sebagian ketentuannya diubah atau dihapus dengan membuat norma baru. ${ }^{30}$

Jimly Asshiddiqie dalam mata kuliah perbandingan konstitusi pada tanggal 28 September 2017 menyampaikan tiga keadaan untuk mempraktekkan omnibus law, yakni UU yang akan diubah berkaitan secara langsung, UU yang akan diubah tidak berkaitan secara langsung, dan UU yang akan

25 Louis Massicotte, "Omnibus Bills in Theory and Practice" (2013) 36:1 Can Parliamentary Rev 13 at 14-15 (for a discussion of omnibus bills in Canadian provinces and in the United States) dikutip dari Adam M. Dodek, Op. Cit., p. 13.

26 Satjipto Rahardjo, Hukum, Masyarakat \& Pembangunan (Bandung: Alumni, 1981), hlm. 29.

27 Kementerian Koordinator Bidang Perekonomian Republik Indonesia, "Omnibus Law Cipta Lapangan Kerja", Op. Cit., hlm. 15.

28 Sarah Safira Aulianisa, "Menakar Kompabilitas Transplantasi Omnibus Law dalam Konteks Peraturan Perundangundangandengan Sistem Hukum Indonesia" (makalah disampaikan dalam Konferensi Ilmiah Badan Penelitian dan Pengembangan Hukum dan HAM: Pemikiran Kritis dan Strategi Pembaruan Hukum,Hotel Puri Denpasar, Jakarta, 29 Oktober 2019), hlm. 29.

29 Vincent Suriadinata, "Penyusunan Undang-Undang di bidang investasi: Kajian Pembentukan Omnibus Law di Indonesia", Jurnal Ilmu Hukum Refleksi Hukum, Volume 4 Nomor 1 (2019), hlm. 131.

30 Kementerian Koordinator Bidang Perekonomian Republik Indonesia (dalam FGD Persiapan Omnibus Law dengan judul: Penyiapan Omnibus Law Ekosistem Investasi (Kemudahan Berusaha)), hlm. 7, dikutip dari Agnes Fitryantica, "Harmonisasi Peraturan Perundang-Undangan Indonesia melalui Konsep Omnibus Law", Jurnal Gema Keadilan (ISSN: 0852-011) Volume 6, Edisi III (2019), hlm. 308. 
diubah tidak berkaitan tetapi dalam praktek bersinggungan. ${ }^{31}$

Dipergunakannya metode omnibus law di Indonesia pada saat ini, menurut Penulis, sangat bisa dipahami. Pertama, karena banyaknya peraturan perundang-undangan yang tidak konsisten satu sama lain. Kedua, sebagai upaya untuk mendorong percepatan pemerintah dalam melayani kepentingan warga negara melalui serangkaian kebijakan kemudahan penciptaan lapangan kerja dan pengembangan UMK-M.

Tidak dapat dipungkiri masih terdapat undang-undang yang satu dengan undangundang yang lain tidak konsisten dan senafas atau sinkron. UU No. 40 Tahun 2007 tentang Perseroan Terbatas (UU PT) memiliki prinsip dan asas yang berbeda dengan apa yang diatur dalam UU No. 17 Tahun 2003 tentang Kekayaan Negara (UU KN) dan UU No. 31 Tahun 1999 tentang Pemberantasan Tindak Pidana Korupsi (UU Tipikor). ${ }^{32}$

Dalam regulasi pertanahan terdapat beberapa permasalahan dengan undangundang sektoral lainnya.UU Nomor 4 Tahun 2009 tentang Pertambangan Mineral dan Batubara (UU Minerba) tidak konsisten dengan Undang-Undang Nomor 5 Tahun 1960 tentang Peraturan Dasar Pokok-Pokok Agraria(UUPA). Karena tidak menjadikan UUPA sebagai sumber hukum. Orientasi UU
Minerba lebih condong kepada produksi bukan konservasi. ${ }^{33}$

Undang-Undang Nomor 41 Tahun 1999 tentang Kehutanan (UUK) tidak konsisten dengan UUPA. UUPA mengakui keberadaan tanah negara, tanah ulayat masyarakat adat dan tanah hak. Sedangkan UUK hanya mengakui keberadaan hutan negara dan hutan hak. ${ }^{34}$

Oleh sebab itu, dipergunakannya metode omnibus law dipandang tepat untuk meningkatkan kemudahan berusaha di Indonesia, yang hingga saat ini masih perlu ditingkatkan. Dalam laporan peringkat kemudahan berusaha (Ease of Doing Business/ EoDB) tahun 2020 yang dirilis Bank Dunia, Indonesia menempati peringkat 73 dari 190 negara. Peringkat ini sama dengan tahun 2019, meskipun dari sisi skor naik menjadi 69,6 dari sebelumnya 67,69 akan tetapi turun satu tingkat dari tahun2018. ${ }^{35}$

Bank Dunia mencatat setidaknya ada lima poin perkembangan positif di Indonesia yaitu:

1. Memulai Usaha

Indonesia membuka pendaftaran izin usaha secara online, menggantikan dokumen fisik dengan elektronik.

2. Memperoleh Sambungan Listrik

Indonesia terus memperbaiki berbagai grid listrik untuk memperbaiki pelayanan. Kapasitas listrik nasional juga terus

31 Vincent Suriadinata, "Penyusunan Undang-Undang di Bidang Investasi: Kajian Pembentukan Omnibus Law di Indonesia", Jurnal Ilmu Hukum Refleksi Hukum, Volume 4 Nomor 1, (2019), hlm. 117.

32 Henry Donald Lbn. Toruan, "Pembentukan Regulasi Badan Usaha Dengan Model Omnibus Law", Jurnal Hukumtôrâ, Vol. 3 No. 1 (2017),hlm. 471.

33 Firman Freaddy Busroh, "Konseptualisasi Omnibus Law dalam Menyelesaikan Permasalahan Regulasi Pertanahan",Jurnal Arena Hukum, Volume 10, Nomor 2 (2017),hlm. 232.

34 Ibid.

35 Lihat CNBC Indonesia, Peringkat Kemudahan Berbisnis di RI Turun, Apa yang Salah?, https://www.cnbcindonesia. com/news/20191122121901-4-117184/peringkat-kemudahan-berbisnis-di-ri-turun-apa-yang-salah(diakses pada tanggal 15 Februari 2020). 
meningkat sehingga sulit ditemui kelangkaan.

3. Pembayaran Pajak Indonesia sudah menerapkan pembayaran pajak secara elektronik.

4. Perdagangan Internasional Indonesia menerapkan deklarasi kepabeanan secara online.

5. Menegakkan Kontrak

Indonesia menerapkan system pendaftaran perselisihan secara online. ${ }^{36}$

Menurut Yustinus Prastowo, Executive Director dari Center for Indonesia Taxation Analysis (CITA) bahwa omnibus law tidak bertentangan dengan UU No. 12 Tahun 2011 tentang Pembentukan PeraturanPerundangundangan sepanjang omnibus law yang dibuat jelas, taat terhadap hierarki aturan, dan menjamin kepastian hukum. ${ }^{37}$

Dengan omnibus law, pemerintah dan parlemen tidak perlu merevisi undang-undang satu per satu, melainkan cukup membuat satu undang-undang baru yang mengamendemen pasal-pasal dalam beberapa undang-undang sekaligus. $^{38}$

Berdasarkan ciri dan karateristiknya, ada beberapa undang-undang di Indonesia yang memiliki sifat seperti omnibus law, yakni Perpu No. 1 Tahun 2017 tentang Akses Informasi Keuangan untuk Kepentingan Perpajakan dan UU No. 11Tahun2016 tentang Pengampunan Pajak. Regulasi ini dibuat secara lintas Undang-Undang sektoral untuk mencabut berbagai ketentuan dari sektorsektor tersebut. ${ }^{39}$

Secara umum omnibus law belum popular di Indonesia, namun terdapat beberapa UU yang sudah menerapkan konsep tersebut, contohnya UU Nomor 9 Tahun 2017 tentang Penetapan Perppu No.1 Tahun 2017 tentang Akses Informasi Keuangan Untuk Kepentingan Perpajakan menjadi UU, yang mencabut: 1). Pasal 35 Ayat (2) \&Pasal 35A UU Ketentuan Umum dan Tata Cara Perpajakan; 2). Pasal 40 \& Pasal41 UU Perbankan; 3). Pasal 47 UU Pasar Modal; 4). Pasal 17, Pasal 27, \& Pasal 55 UU Perdagangan Berjangka Komoditi; 5). Pasal 41 dan Pasal 42 UU Perbankan Syariah. ${ }^{40}$ Adapun manfaat omnibus law, yaitu:

1. Menghilangkan tumpang tindih antar PUU Beberapa peraturan di berbagai sector yang mengatur substansi yang sama/ sejenis namun saling bertentangan/ tumpang tindih dilakukan penataan melalui UU Omnibus sehingga pengaturan di berbagai sector tersebut dapat saling harmoni;

2. Efisiensi proses perubahan/pencabutan PUU

Revisi/pencabutan beberapa peraturan dengan prosedur legislasi biasa membutuhkan waktu dan proses yang lama. Dengan satu UU Omnibus, proses revisi/pencabutan PUU akan lebih efisien dan cepat karena tidak ada pengulangan

\footnotetext{
Ibid.

37 Yustinus Prastowo, "Mujarabkah Omnibus Law Sebagai Obat Lesu Ekonomi Regular Tax Discussion",Center for Indonesia Taxation Analysis, Jakarta, 7 November 2019), hlm. 29.

38 Ibid., hlm. 32.

$39 \quad$ Ibid., hlm. 35.

40 Kementerian Koordinator Bidang Perekonomian Republik Indonesia, "Omnibus Law Cipta Lapangan Kerja", Op. Cit., hlm. 15; Lihat juga H.R. Benny Riyanto, "Omnibus Law Sebagai Penyelesaian Permasalahan Hukum dan Peran Notaris dalam Mendukung ReformasiRegulasi", BPHN, 18 Januari 2020, hlm 6.
} 
berbagai langkah proses legislasi yang harus ditempuh;

3. Menghilangkan ego sektoral yang terkandung dalam berbagai PUU

Berbagai PUU dari beberapa instansi yang saling tumpang tindih dilakukan penataan secara terpadu dengan satu koordinasi/arah kebijakan yang sama sehingga meminimalisir tarik menarik kewenangan. ${ }^{41}$

Namun demikian, penggunaan metode omnibus law tidak boleh menabrak prinsipprinsip negara demokrasi konstitusional atau negara hukum Indonesia.

Adalah Lorne Gunter pernah mengingatkan akan ekses dipergunakannya metode omnibus bill (omnibus law) dengan demokrasi. la mengatakan: "Because of their large size and scope, omnibus bills limit opportunities for debate and scrutiny. Historically, omnibus bills have sometimes been used to pass controversial amendments. For this reason, some consider omnibus bills to be anti-democratic" (Karena ukuran dan cakupannya yang besar, omnibus bill membatasi peluang untuk debat dan pengawasan. Secara historis, omnibus bill kadang-kadang digunakan untuk meloloskan amandemen yang kontroversial. Karena alas an ini, beberapa orang menganggap omnibus bill sebagai anti-demokrasi). ${ }^{42}$

Lalu, bagaimanakah adanya pengaturan mengenai kewenangan Presiden untuk membatalkan Perda baik Perda Kabupaten/ Kota maupun Perda Provinsi dalam RUU Cipta Kerja?
Sebagaimana telah dikemukakan di atas bahwa terkait pembatalan Perda telah ada dua putusan MK, yaitu (1) Putusan MK No. 137/PUU-XIII/2015 tanggal 5 April 2017terkait dengan pembatalan Perda Kabupaten/Kota, dan (2) Putusan MK No. 56/PUU-XIV/2016 tanggal 14 Juni 2018 terkait pembatalan Perda Provinsi.

Putusan MK No. 137/PUU-XIII/2015 tanggal 5 April 2017 merupakan putusan atas permohonan uji materiil atas Pasal 251 ayat (2), ayat (3), ayat (8), dan ayat (4) UU Pemda sepanjang frasa "pembatalan perda Kabupaten/Kota dan peraturan Bupati/ Walikota sebagaimana dimaksud pada ayat (2) ditetapkan dengan keputusan Gubernur sebagai wakil Pemerintah Pusat".

Sedangkan Putusan MK No. 56/PUUXIV/2016 tanggal 14 Juni 2018 merupakan putusan atas permohonan uji materiil atas Pasal 251 ayat (1), ayat (2), ayat (7), dan ayat (8) Undang-Undang Nomor 23 Tahun 2014 tentang Pemerintahan Daerah (UU Pemda).

Putusan MK No. 137/PUU-XIII/2015 tanggal 5 April 2017 membatalkan norma yang menyatakan: Perda Kabupaten/Kota dibatalkan oleh Gubernur sebagai wakil Pemerintah Pusat, Menteri membatalkan Perda Kabupaten/Kota dalam hal gubernur sebagai wakil Pemerintah Pusat tidak membatalkan Perda Kabupaten/Kota, dan pembatalan Perda Kabupaten/Kota ditetapkan dengan keputusan Gubernur sebagai wakil Pemerintah Pusat.

\footnotetext{
41 Kementerian Koordinator Bidang Perekonomian Republik Indonesia, "Omnibus Law Cipta Lapangan Kerja", Op. Cit.,hlm. 14; Lihat juga H.R. Benny Riyanto, "Omnibus Law Sebagai Penyelesaian Permasalahan Hukum dan Peran Notaris dalam Mendukung ReformasiRegulasi", Op. Cit.,hlm 7.

42 Lorne Gunter, Omnibus bills in Hill History, https://torontosun.com/2012/06/18/omnibus-bills-in-hill-history/ wcm/5b85232b-b8b4-4c9b-b5b7-9480b9821292 (diakses pada tanggal 11 Februari 2020).
} 
Sedangkan Putusan MK No. 56/PUUXIV/2016 tanggal 14 Juni 2018 membatalkan norma yang mengatur bahwa Perda Provinsi dibatalkan oleh Menteri.

Pertanyaannya, apakah jika dalam RUU Cipta Kerja mengatur norma lain dalam hal ini menyatakan Perda Provinsi dan/atau Perda Kabupaten/Kota dinyatakan tidak berlaku dengan Peraturan Presiden, yang ini berarti bahwa Perda Provinsi dan/atau Perda Kabupaten/Kota dibatalkan oleh Presiden, tidak berlawanan dengan Putusan MK No. 137/PUU-XIII/2015 tanggal 5 April 2017 dan Putusan MK No. 56/PUU-XIV/2016 tanggal 14 Juni 2018?

Penulis berpendapat bahwa meskipun norma yang diatur dalam RUU Cipta Kerja adalah tidak sama dengan norma yang dibatalkan berdasarkan kedua putusan MK a quo, rumusan norma dalam RUU Cipta Kerja yang mengatur bahwa pembatalan Perda Provinsi dan/atau Perda Kabupaten/ Kota menjadi kewenangan Presiden dan ditetapkan dalam bentuk Peraturan Presiden sebagai bentuk regeling bukan beschikking, tidak tepat dari sisi teori hukum.

Pertama, meskipun norma yang diatur berbeda sebagaimana telah disebutkan di atas, akan tetapi secara materiil merujuk pada Putusan MK No. 137/PUU-XIII/2015 tanggal 5 April 2017 dan Putusan MK No. 56/PUU-XIV/2016 tanggal 14 Juni 2018 telah ditegaskan bahwa pembatalan Perda dalam hal ini Perda Kabupaten/Kota dan/atauPerda Provinsi menjadi ranah kewenangan konstitusional Mahkamah Agung (MA). $\mathrm{Hal}$ ini secara tersurat tercantum dalam pertimbangan hukum baik dalam Putusan MK No. 137/PUU-XIII/2015 tanggal 5 April $2017^{43}$ maupun Putusan MK No. 56/PUU-XIV/2016 tanggal 14 Juni $2018 .{ }^{44}$

Apakah pertimbangan hukum bisa mengikat secara hukum seperti halnya amar putusan? Van Boneval Faure menyatakan, "kekuatan moral suatu putusan hakim terletak pada pertimbangan-pertimbangannya (in die motiveringligt de zedelijkkracht van het vonnis)". ${ }^{45}$

Merujuk pada doktrin di atas, penulis berpendapat bahwa meskipun tertuang dalam pertimbangan hukum seyogyanya Pemerintah dalam hal ini Presiden memperhatikan orginal intent dari putusan Mahkamah (MK) dan mematuhinya. Yang dimaksud bahwa pembatalan Perda dalam hal ini Perda Kabupaten/Kota dan/atau Perda Provinsi menjadi ranah kewenangan konstitusional Mahkamah Agung (MA).

Kedua, pengaturan norma dalam RUU Cipta Kerja yang menentukan bahwa Perda Provinsi dan/atau Perda Kabupaten/Kota dibatalkan oleh Presiden, dengan hanya mengubah ketentuan Pasal 251 UU Pemda adalah tidak menyelesaikan permasalahan inkonsistensi undang-undang, sebagaimana maksud dan tujuan adanya metode omnibus law (RUU Cipta Kerja).

Hal ini mengingat pada undang-undang yang lain justru masih melekat pengaturan bahwa pembatalan Perda dalam hal ini Perda 
Kabupaten/Kota dan/atau Perda Provinsi menjadi ranah kewenangan konstitusional Mahkamah Agung (MA).

Dalam Pasal 9 ayat (2) UU No. 12 Tahun 2011 tentang Pembentukan Peraturan Perundangundangan sebagaimana telah diubah dengan UU No. 15 Tahun 2019 disebutkan, "Dalam hal suatu Peraturan Perundang-undangan di bawah Undang-Undang diduga bertentangan dengan Undang-Undang, pengujiannya dilakukan oleh Mahkamah Agung".

Pasal 20 Ayat (2) huruf b UU No. 48 Tahun 2009 tentang Kekuasaan Kehakiman, menyebutkan, "MahkamahAgung berwenang; ... b. menguji peraturan perundang-undangan di bawah undang-undang terhadap undangundang".

Pasal 31 Ayat (1) UU No. 14 Tahun 1985 tentang Mahkamah Agung sebagaimana diubah terakhir dengan UU No. 3 Tahun 2009 menyatakan, "Mahkamah Agung mempunyai wewenang menguji peraturan perundangundangan di bawah undang-undang terhadap undang-undang".

Ketiga, terkait adanya ketentuan Pasal 9 ayat (2) UU No. 12 Tahun 2011 tentang Pembentukan Peraturan Perundangundangan sebagaimana telah diubah dengan UU No. 15 Tahun 2019, Pasal 20 Ayat (2) huruf b UU No. 48 Tahun 2009 tentang Kekuasaan Kehakiman, dan Pasal 31 Ayat (1) UU No. 14 Tahun 1985 tentang Mahkamah Agung sebagaimana diubah terakhir dengan UU No. 3 Tahun 2009, bahwa kewenangan konstitusional untuk membatalkan Perda dalam hal ini Perda Kabupaten/Kota dan/ atau Perda Provinsi merupakan kewenangan atributif dari Mahkamah Agung (MA). Kewenangan MA untuk membatalkan atau menguji Perda ini merupakan kewenangan atributif karena secara langsung bersumber dari undang-undang, ${ }^{46}$ sebagaimana telah disebutkan di atas.

Bahkan kewenangan yang dimiliki MA ini dipertegas oleh Putusan MK No. 137/PUUXIII/2015 tanggal 5 April 2017 dan Putusan MK No. 56/PUU-XIV/2016 tanggal 14 Juni 2018 yang menyatakan pembatalan Perda dalam hal ini Perda Kabupaten/Kota dan/atau Perda Provinsi menjadi ranah kewenangan konstitusional Mahkamah Agung (MA).

\section{Penutup}

Berdasarkan paparan di atas, dapat ditarik kesimpulan, sebagai berikut: pertama, Putusan MK No. 137/PUU-XIII/2015 tanggal 5 April 2017 dan Putusan MK No. 56/PUUXIV/2016 tanggal 14 Juni 2018 yang di dalam pertimbangan hukumnya menyatakan bahwa pembatalan Perda dalam hal ini Perda Kabupaten/Kota dan/atau Perda Provinsi menjadi ranah kewenangan konstitusional Mahkamah Agung (MA). Kedua, adanya ketentuan Pasal 166 angka 3 RUU Cipta Kerja yang mengubah Pasal 251 Undang-Undang Nomor 23 Tahun 2014 tentang Pemerintahan Daerah sebagaimana diubah terakhir dengan Undang-Undang Nomor 9 Tahun 2015 (UU Pemda) yang menentukan bahwa Perda Provinsi dan/atau Perda Kabupaten/Kota dan peraturan bupati/walikota dicabut dan dinyatakan tidak berlaku dengan Peraturan Presiden adalah tidak tepat. Baik dilihat dari sisi original intent dari Putusan MK No.

46 Ridwan HR, Hukum Administrasi Negara,Ed. Revisi, Cet. 13, (Jakarta: Rajawali Pers,2017), hlm. 102. 
137/PUU-XIII/2015 tanggal 5 April 2017 dan Putusan MK No. 56/PUU-XIV/2016 tanggal 14 Juni2018, dari sisi teori perubahan undangundang, dan dari sisi teori kewenangan lembaga negara.

Berdasarkan hal tersebut, penulis perlu menyarankan kepada Pemerintah dalam hal ini Presiden Jokowi dan DPR RI sebagai Pembentuk Undang-Undang untuk menyempurnakan rumusan norma yang diatur dalamPasal 166 angka 3 RUU Cipta Kerja yang mengubah Pasal 251 Undang-UndangNomor 23 Tahun 2014 tentang Pemerintahan Daerah sebagaimana diubah terakhir dengan Undang-Undang Nomor 9 Tahun 2015 (UU Pemda). Rumusan norma dimaksud harus diselaraskan atau disinkronisasikan dengan undang-undang maupun putusan Mahkamah Konstitusi (MK) terkait yang mengatur pembatalan Perda baik Perda Provinsi dan/atau Perda Kabupaten/ Kota.

\section{Daftar Pustaka}

\section{Buku}

Arikunto, Suharsini, Manajemen Penelitian (Jakarta:PT Rineka Cipta, 1993).

Dirdjosisworo, Soedjono,Pengantar IImu Hukum(Jakarta: Rajagrafindo Persada, 2001).

Rahardjo, Satjipto, Hukum, Masyarakat \& Pembangunan (Bandung: Alumni, 1981).

Rahardjo, Satjipto, Ilmu Hukum (Bandung: Citra Aditya Bakti, 2000).

Ridwan HR, HukumAdministrasi Negara, Ed. Revisi, Cet. 13 (Jakarta: Rajawali Pers,2017).

Sumardjono dan Maria S.W.,Pedoman Pembuatan Usulan Penelitian (Yogyakarta: t.p., 1989).

Setiawan, Aneka Masalah Hukum dan Hukum Acara Perdata (Bandung: Penerbit Alumni, 1992).

Soekanto, Soerjono,Pengantar Penelitian Hukum (Jakarta: UI Press, 1982).

Soekanto, Soerjono dan Sri Mamudji, Penelitian Hukum Normatif Suatu Tinjauan Singkat(Jakarta: Rajawali Pers, 2004).
Widodo, Erna dan Mukhtar, Konstruksi Ke Arah Penelitian Deskriptif (Yogyakarta: Avyrouz, 2000).

Wignjosoebroto, Soetandyo, Hukum, Konsep dan Metode (Malang: Setara Press, 2013).

\section{Makalah/Artikel/Prosiding/Hasil Penelitian}

Aulianisa, Sarah Safira, "Menakar Kompabilitas Transplantasi Omnibus Law dalam Konteks Peraturan Perundang-undangandengan Sistem Hukum Indonesia", (makalah disampaikan dalam Konferensi Ilmiah Badan Penelitian dan Pengembangan Hukum dan HAM: Pemikiran Kritis dan Strategi Pembaruan Hukum, Hotel Puri Denpasar, Jakarta, 29 Oktober 2019).

Busroh, Firman Freaddy, "Konseptualisasi Omnibus Law Dalam Menyelesaikan Permasalahan Regulasi Pertanahan", Jurnal Arena Hukum, Volume 10, Nomor 2 (2017).

Dodek, Adam M., "Omnibus Bills: Constitutional Constraints and Legislative Liberations", Ottawa Law Review, Vol. 48, No. 1 (2017), https://papers.ssrn.com/sol3/papers. cfm?abstract_id=2889773(diakses 11 Februari 2020).

Fitryantica, Agnes, "Harmonisasi Peraturan Perundang-Undangan Indonesia melalui Konsep Omnibus Law", Jurnal Gema Keadilan (ISSN: 0852-011) Volume 6, Edisi III (2019).

Kementerian Koordinator Bidang Perekonomian Republik Indonesia, "Omnibus Law Cipta Lapangan Kerja" (2020).

Prastowo, Yustinus, "Mujarabkah Omnibus Law Sebagai Obat Lesu Ekonomi Regular Tax Discussion" (makalah disampaikan di Center for Indonesia Taxation Analysis, Jakarta, 7 November 2019).

Riyanto, H.R. Benny, "Omnibus Law Sebagai Penyelesaian Permasalahan Hukum dan Peran Notaris dalam Mendukung Reformasi Regulasi" (makalah disampaikan di BPHN, 18 Januari 2020).

Suriadinata, Vincent, "Penyusunan UndangUndang di Bidang Investasi: Kajian Pembentukan Omnibus Law di Indonesia", Jurnal Ilmu Hukum Refleksi Hukum, Volume 4 Nomor 1 (2019).

Toruan, Henry Donald Lbn., "Pembentukan Regulasi Badan Usaha Dengan Model Omnibus Law", Jurnal Hukum tô-râ, Vol. 3 No. 1 (2017). 


\section{Internet}

Detik.com, "Alasan Jokowi Kebut Omnibus Law: Kita Mengalami Obesitas Regulasi", https://finance.detik.com/berita-ekonomibisnis/d-4875968/alasan-jokowi-kebutomnibus-law-kita-mengalami-obesitasregulasi (diakses 15 Februari 2020).

Hukum Online, "Menimbang Konsep Omnibus Law Bila Diterapkan di Indonesia",https:// www.hukumonline.com/berita/baca/ It58a6fc 84 b8ec3/menimbang-konsepomnibus-law-bila-diterapkan-di-indonesia/ (diakses 11 Februari 2020).

CNBC Indonesia, "Peringkat Kemudahan Berbisnis di RI Turun, Apa yang Salah?", https://www. cnbcindonesia.com/news/201911221219014-117184/peringkat-kemudahan-berbisnis-diri-turun-apa-yang-salah (diakses 15 Februari 2020).

Gunter, Lorne, "Omnibus bills in Hill history", Sun Media, https://torontosun.com/2012/06/18/ omnibus-bills-in-hill-history/wcm/5b85232bb8b4-4c9b-b5b7-9480b9821292 (diakses 11 Februari 2020).

\section{Peraturan}

Undang-Undang Dasar Negara Republik Indonesia Tahun 1945.

Undang-Undang Nomor 30 Tahun 2014 tentang Administrasi Pemerintahan.
Undang-Undang Nomor23 Tahun 2014 tentangPemerintahan Daerah sebagaimana telah beberapa kali diubah, terakhir dengan Undang-Undang Nomor 9 Tahun 2015 tentang Perubahan Kedua atas Undang-Undang No. 23 Tahun 2014 tentang Pemerintahan Daerah.

Undang-Undang Nomor 14 Tahun 1985 tentang Mahkamah Agung sebagaimana telah beberapa kali diubah,terakhir dengan Undang-Undang Nomor 3 Tahun 2009 tentang Perubahan Kedua atas Undang-Undang Nomor 14 Tahun 1985 tentang Mahkamah Agung.

Undang-UndangNomor 48 Tahun 2009 tentang Kekuasaan Kehakiman.

Undang-UndangNomor12 Tahun 2011 tentang Pembentukan Peraturan Perundang-undangan sebagaimana telah diubah dengan UndangUndangNomor 15 Tahun 2019 tentang Perubahan atas Undang-Undang Nomor 12 Tahun 2011 tentang Pembentukan Peraturan Perundang-Undangan.

Rancangan Undang-Undang tentang Cipta Kerja.

\section{Putusan Pengadilan}

Putusan Mahkamah Konstitusi Nomor 137/PUUXIII/2015 tanggal 5 April 2017.

Putusan Mahkamah Konstitusi Nomor 56/PUUXIV/2016 tanggal 14 Juni 2018. 